\title{
TRAGEDIA I SCEPTYCYZM
}

Idea tragizmu powstała w krótkim, intensywnym rozkwicie greckiej sztuki tragicznej, która kilka elementów ludzkiej egzystencji: przypadek, winę, indywidualność, wspólnotę, samowiedzę, sprawczość, zdeterminowanie i wolność wyboru powiązała w nieznany przedtem sposób. Tragicy odkryli taką postać ludzkiego losu, w której działający pada $\mathrm{z}$ konieczności ofiarą własnego działania, lecz pomimo że zachodzi konieczność, a działający jest ofiarą, ciąży na nim wina za powstałe zło i własny upadek. Późniejsi komentatorzy, szczególnie twórcy XIX-wiecznej niemieckiej filozofii tragedii ${ }^{1}$, uważali, że tragedia wyraża istotną prawdę o ludzkim życiu resp. o położeniu człowieka w świecie. Próba określenia tej prawdy w sposób niemetaforyczny, właściwy filozofii, prowadzi jednak do dotkliwych aporii: w sytuacji tragicznej załamują się bowiem relacje między czynem i odpowiedzialnością, koniecznością i wolnością, działaniem i podleganiem oddziaływaniu.

Filozoficzna interpretacja tragedii odwoływała się najczęściej do pozytywnego konfliktu sił lub wartości: Friedrich Nietzsche (1907/2011) mówił, na przykład, o siłach wywołanych zderzeniem roszczeń jednostki i wspólnoty, a Max Scheler (1976) o konflikcie wartości. Pozytywne interpretacje tragedii

Prof. dr hab. Robert PiŁat - Uniwersytet Kardynała Stefana Wyszyńskiego, Wydział Filozofii Chrześcijańskiej, Instytut Filozofii, Katedra Teorii Poznania; adres do korespondencji: ul. Wóycickiego 1/3, bud. 23, 01-938 Warszawa; e-mail: r.pilat@uksw.edu.pl; ORCID: https:// orcid.org/0000-0001-7712-7032.

Mgr Martyna Filcek - Uniwersytet Kardynała Stefana Wyszyńskiego, Wydział Filozofii Chrześcijańskiej, Instytut Filozofii, doktorantka; adres do korespondencji: ul. Wóycickiego 1/3, bud. 23, 01-938 Warszawa; e-mail: filcekmartyna@gmail.com; ORCID: https://orcid.org/00000002-3689-3483.

${ }^{1}$ Bliższą analizę XIX-wiecznej fillozofii tragedii, w tym szczególnie istotnych koncepcji Schellinga i Hegla, zawierają książki Pétera Szondiego (zob. Szond 2020) i polemizującego z nim Joshuy Billingsa (zob. BILlings 2011). Szerszą panoramę XIX-wiecznej niemieckiej filozofii i tragedii znaleźć można w HüHN i Schwab 2011. 
dobrze opisują faktyczność tragedii (siły i motywy działające na bohatera tragicznego) oraz częściowo świadomość tragiczną, czyli to, jak bohater tragiczny postrzega i rozumie swoją sytuację w świecie. W mniejszym stopniu pozwalają zrozumieć treść doświadczenia tragicznego i czynu tragicznego, a także egzystencjalny i moralny sens winy tragicznej. Sądzimy, że te trzy ostanie aspekty sytuacji tragicznej da się zrozumieć lepiej, przyjmując, że w samym rdzeniu sytuacji tragicznej tkwi pewien akt negatywny. Celem tego artykułu jest analiza tego aktu, nawiązująca do rozsianych w literaturze przedmiotu intuicji, które jednak nie były dotąd połączone w spójnej koncepcji ${ }^{2}$.

Akt negatywny, należący istotnie do sytuacji tragicznej, jest - w najogólniejszym ujęciu — odmową zaakceptowania swojej pozycji w świecie. Odmowa ta przybiera dwie postaci: pierwsza polega na odrzuceniu własnej wiedzy o świecie (w skrajnej postaci: odrzucenie z góry wszelkiej wiedzy), druga - na odrzuceniu więzi łączących bohatera z innymi ludźmi (w skrajnej postaci: odrzucenie z góry wszelkich więzi). Często akty te występują jednocześnie, a ich konsekwencją jest autoalienacja resp. niezdolność do bycia sobą-w-świecie. Chcemy podjąć analizę kluczowego aktu zerwania relacji ze światem - radykalnego sceptycyzmu i krok po kroku pokazać, jak łączy się on ze świadomością tragiczną. Bronimy tezy, że ów akt negatywny czy radykalny sceptycyzm jest nie tylko istotny, ale fundamentalny dokonanie sceptycznego odrzucenia, którego sens tu wyjaśnimy, poprzedza, naszym zdaniem, inne elementy konstytutywne sytuacji tragicznej.

Rozróżnienie pozytywnego i negatywnego aktu w strukturze tragedii nakłada się na inny podział, który naszym zdaniem rzuca światło na istotę doświadczenia tragicznego. W sytuacji tragicznej da się wyróżnić dwie warstwy: - Warstwa pierwsza: Bohater tragiczny konstatuje nieszczęście (przeszłe, obecne lub nadchodzące) i opiera mu się wykorzystując swoje zasoby: energię działania, wiedzę, więzi z ludźmi. Przekonuje się jednak, że wszystkie te zasoby zostają wchłonięte i przetworzone przez zewnętrzny bieg zdarzeń (w klasycznej wykładni jest to los czy wola bogów) w taki sposób, że obracają się przeciwko bohaterowi. Działanie obmyślone jako obrona okazuje się bowiem częścią szerszego procesu, w którym podjęte działanie zmienia sens i staje się przyczyną nieprzewidzianego i ostatecznego nie-

\footnotetext{
${ }^{2}$ Ten stan rzeczy widać już na pierwszy rzut oka, jako że autorzy współcześni, z których nauczyliśmy się i zaczerpnęliśmy najwięcej (Christopher Menke, Martha Nussbaum, Stanley Cavell) ani nie dążą świadomie do zbudowania takiej koncepcji, ani nawet nie odnoszą się do siebie wzajemnie - z małymi, niewiele znaczącymi wyjątkami.
} 
szczęścia. Wiedza, nawet najdoskonalsza, okazuje się bezradna wobec przeciwnika, który, mówiąc metaforycznie, wie wszystko to, co wie bohater, a ponadto ma swoje, nieznane bohaterowi, cele. Bohater tragiczny nie rozumie zależności między swoimi czynami i nieszczęściem, które następuje.

- Warstwa druga: Bohater tragiczny odnosi się do siebie; konstatując swoją bezradność, uznaje ją za istotny składnik swojej tożsamości. Widzi siebie w swoim daremnym oporze, a przez uznanie swojej roli przyznaje się do zawinionej porażki. Jest ona zawiniona, ponieważ bohater tragiczny nie tylko uznaje, że jego działanie zakończyło się porażką, lecz rozumie, że jego czynem była wtaśnie porażka ${ }^{3}$.

Fundamentalny negatywny akt, który chcemy tu wydobyć, lokuje się w drugiej warstwie sytuacji tragicznej. W historii interpretacji tragedii jego obecność uświadomiono sobie później i jest on trudniejszy do zrozumienia niż pozytywny konflikt wartości czy sił. Pewien poetycki wgląd w tragiczną negację był wprawdzie obecny od początku istnienia tragedii jako gatunku scenicznego, co pokazuje Martha Nussbaum w The Fragility of Goodness (Nussbaum 1986), lecz uwyraźnił się dopiero w nowożytności, szczególnie w tragediach Szekspira. Głównym komponentem nowożytnej postawy jest bowiem radykalny sceptycyzm (CAVELL 2013), sięgający głębiej niż klasyczne filozoficzne wątpliwości dotyczące poznania i uzasadniania przekonań. Nowożytny bohater tragiczny nie tyle ubolewa z powodu niedoskonałości poznania, które nie pozwala mu odwrócić losu na własną korzyść, co odżegnuje się od wiedzy (disowns knowledge), odrzuca ją i szydzi z niej. Nowożytny bohater tragiczny jest uczestnikiem przenikniętym wolą nieuczestniczenia, człowiekiem czynu przenikniętym odmowa działania, a co najważniejsze - podmiotem poznania przenikniętym pogarda dla wiedzy.

Wyjaśnienie negatywnego aktu u podłoża tragedii pozwoli również odpowiedzieć na pytanie, dlaczego bohater tragiczny nie rozumie własnej sytuacji. Niezrozumienie własnego bycia-w-świecie w sytuacji nieszczęścia (pogubienie się) jest częstym zjawiskiem i niekonieczne wiąże się z tragedią. Niewiedza tragiczna jest jednak innej natury: powstaje na skutek uprzedniego odrzucenia poznawczych i emocjonalnych więzi ze światem. Śledząc głębię tego odrzucenia, widzimy, że nie jest ono skutkiem obiektywnego nieszczęścia,

\footnotetext{
${ }^{3} \mathrm{Z}$ tragedią wiąże się poczucie konieczności. Zgodnie $\mathrm{z}$ proponowaną tu interpretacją płynie ona stąd, że świat, z którym zmaga się podmiot, posługuje się jego własnymi zasobami - tym, co on sam dodał do rzeczywistości, zmuszony do stawienia oporu. Tożsamość działającego i doświadczającego (choć przedzieleni są łukiem relacji ze światem) jest podstawą tragicznej nieuchronności.
} 
wchodzącego w skład pierwszej warstwy sytuacji tragicznej, lecz jego przyczyną. Strzałki zależności nie są tu wprawdzie ani stałe, ani pewne, lecz przejawiają pewną prawidłowość - układają się w strukturę kolistą:

$\longrightarrow$ nieszczęście $\longrightarrow$ konieczność działania $\longrightarrow$ nowa rzeczywistość,

jeszcze mniej zrozumiała z uwagi na uwikłanie podmiotu $\rightarrow$ działanie

w nowej niezrozumiałej rzeczywistości $\rightarrow$ ostateczne nieszczęście

$\rightarrow$ uświadomienie sobie, że jest się przyczyną ostatecznego nieszczęścia, $\rightarrow$ redukcja własnej podmiotowości i sprawczości

$\rightarrow$ alienacja wystawiająca na nieszczęście $\rightarrow$.

Na mocy tej kolistej zależności powstaje spirala upadku podmiotu. Myślicielem, który zgłębił to zjawisko, był Lew Szestow i to jemu poświęcamy ostatnią część tych rozważań. Jego stanowisko w kwestii tragizmu jest tyleż doniosłe, co paradoksalne. W obliczu tragedii należy, jego zdaniem, wstrzymać proces racjonalizacji, nie powiększać zasobów dociekającej refleksji, ta bowiem wzmaga tylko doświadczenie tragiczne. Zamiast tego proponuje wytrwanie $\mathrm{w}$ kondycji, którą nazwał niezakorzenieniem.

\section{TRAGICZNA NEGACJA \\ JAKO UNIEWAŻNIENIE CUDZEGO ROSZCZENIA}

W swojej głośnej książce The Fragility of Goodness Martha Nussbaum zmierza do rekonstrukcji relacji między dobrem i kontyngencją — relacji pozostającej - niesłusznie, jak sądzi - w cieniu etyki normatywnej, gdzie dobro jest efektem prawidłowego wyboru pomiędzy działaniami resp. zasadami postępowania. Nussbaum uważa, że starożytna tragedia, szczególnie trylogia Ajschylosa Oresteia, wyraża jasną świadomość kruchości dobra w przygodnym (contingent) świecie: Dobro nie jest tu funkcją naszych wyborów (zob. Nussbaum 1986, 46-47). W pierwszej części trylogii, Agamemnonie tytułowy bohater ma z nakazu bogów poświęcić na ołtarzu córkę. Konflikt między wartościami: życie córki versus dobro społeczności (nakaz bogów) nie zostaje rozwiązany za pomocą decyzji czy reguły wnoszącej sprawiedliwość. Więcej nawet, zniesiony tu zostaje wybór jako taki, choć zostaje zachowana odpowiedzialność. Nussbaum polemizuje w tej kwestii z Jean-Paulem Sartre'em ${ }^{4}$ i Richardem Harem (Nussbaum 1986, 31-32), przed-

\footnotetext{
${ }^{4} \mathrm{~W}$ znanym Sartre'owskim przykładzie syna stojącego przed wyborem: wstąpić do partyzantki czy zostać przy potrzebującej go matce filozof przedstawia wybór, którego wprawdzie nie da się
} 
stawiającymi sytuację tragiczną tak, by ostatecznie sprowadzała się do wyboru. Szczególnie istotna jest dyskusja z Harem, który interpretuje nierozwiązywalny konflikt jako dotyczący racji czy wartości i następnie podaje ogólną metodę jego rozwiązania z punktu widzenia etyki zasad. W sytuacji konfliktu należy mianowicie na nowo zinterpretować regułę działania, włączając elementy przygodne $\mathrm{w}$ jej treść, np. zamiast ogólnego zakazu zabijania, który prowadzi do aporii w sytuacji wojny, pojawiałby się zakaz zabijania członków własnej rodziny, klanu czy narodu. Etyka, czyli system przekonań, który wyjaśnia, uzasadnia i implikuje postępowanie moralnie dobre (zdaniem danej społeczności), zostaje zmodyfikowana, lecz nie traci przez to pozycji normatywnej w stosunku do przygodnego świata - etyka nie przeradza się w pragmatykę.

Nussbaum zgadza się z Harem, że w proponowanych przekształceniach zostaje zachowany rdzeń etyczności, lecz uważa, że w jego interpretacji znika istotna część odpowiedzialności działającego. W sytuacji tragicznej dochodzi do przewinienia niezależnie od tego, jak zmieni się zasady. Źródłem winy tragicznej nie jest bowiem niezgodność z jakąś zasadą, lecz naruszenie roszczeń równorzędnych podmiotów ${ }^{5}$. Gdyby nie istniały roszczenia innych, nikt nie mógłby zgłosić własnego roszczenia - nawet tak podstawowego jak prawo do istnienia. Chór mówi o Agamemnonie, że poświęcając Ifigenię działa wprawdzie z nakazu bogów, lecz nie unika w ten sposób winy. Nakaz bogów nie ma bowiem mocy usuwania roszczeń równorzędnych podmiotów. W swoim działaniu (poświęcenie Ifigenii) Agamemnon nie tyle wybiera swoim zmysłem etycznym jedno $l u b$ drugie roszczenie (dobro wspólnoty versus dobro córki), lecz wybiera obcą, nieludzką wolę bogów, to znaczy roszczenie, które jest zarazem ponad roszczeniami, a zatem pewną przemoc (Nussbaum 1986, 26). Za ten wybór właśnie zostaje obwiniony przez chór - nie za sam czyn, który był i tak przesądzony przez bogów, lecz za gotowość na ten czyn, za wewnętrzną zgodę na podeptanie wszelkich partykularnych roszczeń (NussBaum 1986, 36). Ta zgoda to zarazem próba umysłu postawienia się w tej samej uprzywilejowanej pozycji, ponad naturalną grą ludzkich interesów i praw.

Interpretacja Nussbaum pomaga $\mathrm{w}$ odsłonięciu fundamentalnej negacji tkwiącej $\mathrm{w}$ centrum sytuacji tragicznej. Wiele pytań pozostawia jednak bez

\footnotetext{
wystarczająco uzasadnić, bo oba roszczenia pozostają w mocy również po jego dokonaniu, tym niemniej, choć absurdalny, jest to wybór. (Zob. SARTRE 1998, 40-46; NusSBAum 1986, 31).

${ }^{5}$ Jak zauważył Bernard Williams, nawet usuniecie się z grona intencjonalnych sprawców, czyli powściągnięcie własnego pragnienia, może nie wystarczyć do tego, by uniknąć winy wynikającej z pogwałcenia roszczenia (za: Nussbaum 1986, 29).
} 
odpowiedzi. Ajschylos uznaje ${ }^{6}$ opisaną wyżej sytuację za ludzką kondycję, widzi, że rzeczywistość działa przeciw jednostce pragnącej powołać się na swoje poczucie dobra. Jest tak dlatego, że bogowie ustalają reguły gry, ale zarazem są graczami, mają swoje interesy. Ale po co bogowie potrzebują reguł? Czy nie wystarczyłaby sama siła? Pytanie to można oczywiście wyrazić bez mitologicznej personifikacji: Czy nie wystarczy uznać, że świat przeciwstawia się człowiekowi przez siły przyczynowe? Czy trzeba zakładać, że to wrogie działanie świata ma w sobie zawarty logos — że jest $\mathrm{w}$ istocie zagadka, której rozwiązanie mogłoby (choć w tragedii tak się nie dzieje) uwolnić człowieka od nieuchronności losu i winy?

Owszem, siła (przemoc) występuje wyraźnie w pierwszej z wyróżnionych przez nas warstw sytuacji tragicznej i często jest wystarczającym opisem tego, co tam zachodzi, mianowicie pierwotnej energii pragnienia, pierwotnej ambicji. Natomiast w obrębie drugiej warstwy odwołanie się do siły czy zderzających się energii nic nie daje; węzeł tragiczny pojawia się tu bowiem w obrębie wewnętrznego doświadczenia bohatera, a nie w zewnętrznej sferze działania; pojawia się jako pathos podmiotu - realizuje się w percepcji i osądzie (szczególnie w osądzie samego siebie). Podmiot widzi daremność oporu, rozumie konieczność porażki i uznaje się za winnego ${ }^{7}$. Dlaczego jednak we wszystkich tych aktach pojawia się charakterystyczne dla tragedii poczucie konieczności? Otóż „przeciwnik” zmienia reguły gry (zastawia pułapkę) właśnie pod wpływem oporu stawianego przez podlegający przemocy podmiot. Trudno to wyjaśnić, nie uciekając się do personifikowania rzeczywistości. Z filozoficznych względów nie jest to jednak wskazane. Rzeczywistość nie ma zamysłów, nie jest przeciwnikiem, dopóki bohater w swojej desperacji jej tak nie nazwie; nie stoi wobec niego jako siła, zanim on nie stanie wobec samego siebie. Tragedia powstaje wtedy, kiedy rzeczywistość jest dana $w$ świetle samowiedzy podmiotu. Można nawet wzmocnić to twierdzenie, nadając mu charakter ontologiczny: rzeczywistość istnieje w trybie samowiedzy podmiotu. Dlatego, sięgając po metonimię, można powiedzieć, że działający zastawia pułapkę sam na siebie.

Nussbaum przedstawia Ajschylosa jako kogoś, kto pojął, że pole konfliktu między roszczeniami jest podstawową rzeczywistością, w której

\footnotetext{
${ }^{6}$ Uznanie wyraża się w tym, że po zrozumieniu konieczności Agamemnon dostraja swoje uczucia i cały swój stan wewnętrzny do tej prawdy o konieczności (NuSSBAUM 1986, 34). Za to właśnie zostaje obwiniony przez chór, nie za czyn, który był przesądzony przez bogów, lecz za gotowość na ten czyn, zgodę nań (36).

${ }^{7}$ Ten aspekt tragedii, osądzenie samego siebie, rozwija interesująco Christopher Menke (2005, 40-46).
} 
żyjemy. Ani rozkład tych roszczeń, ani rozsadzenie między nimi nie leży w kompetencji pojedynczego podmiotu. Kiedy próbuje on wziąć na siebie te prerogatywy, znajduje się w fałszywej sytuacji Edypa, podejmującego się osądu, który wydać może tylko wspólnota ${ }^{8}$. Podmiot taki staje nieuchronnie przez alternatywą dwóch porażek: (1) Może wybrać uczestnictwo w całości, a to znaczy również $w$ systemie skonfliktowanych roszczeń, przyjmując związane $\mathrm{z}$ tym reguły gry (u Ajschylosa reguły te są równoważne woli bogów) i konsekwentnie zamknąć oczy na każde pojedyncze roszczenie (w Agamemnonie było to dobro Ifigenii). W ten sposób ponosi klęskę moralna, staje się krzywdzicielem. (2) Może wybrać drogę emancypacji i oporu wobec reguł gry i ponieść klęskę tragiczna — opór bowiem okazuje się nie tyle wygaszeniem przyczyn nieszczęścia, co wzbudzeniem w rzeczywistości nowych sił, którym bohater nie zdoła się już przeciwstawić; paradoksalnie emancypacja stawia go ostatecznie w pozycji ofiary ${ }^{9}$. Staje się tym, który musi się poświęcić dla utrzymania równowagi we wspólnocie roszczeń.

W każdym przypadku będzie winny i w żadnym $\mathrm{z}$ tych dwóch przypadków nie ma sposobu na uzasadnienie swego postępowania (ani też na ucieczkę, wymknięcie się z owego pola sił). Agamemnon wybiera posłuszeństwo bogom, a zatem uczestnictwo w całości. Nie uzasadnia swego kroku przez deklarację, że dobro jego córki niewiele dlań znaczy, bo tak nie jest (nie ma na to żadnego uzasadnienia $\mathrm{w}$ tekście $\mathrm{i}$ byłoby to zresztą dramaturgicznie nieuzasadnione). Może tylko zamknać oczy na to dobro, czyli stwierdzić jego irrelewancję z punktu widzenia uczestniczenia w rzeczywistości ${ }^{10}$. Mówiąc dosadnie: jeśli udaje nam się w pełni uczestniczyć w świecie społecznym, to tylko dlatego, że niektóre słuszne roszczenia innych ludzi są wzgardzone, uznane za nieistotne. Tego właśnie dotyczy tragedia.

Nussbaum pokazuje jak akt negatywny, o którym tu mowa, ulega konkretyzacji u Sofoklesa. Przybiera postać intencjonalną i systematyczną; jest mianowicie unikaniem i odżegnywaniem się od pewnych dóbr za pomocą ich redukcji do innych dóbr. Kreon w Antygonie sprowadza wszystkie dobra do

\footnotetext{
${ }^{8}$ Ajschylos rozumiał to, ponieważ w Eumenidach, trzeciej części Orestei, przedstawił wyłanianie się systemu prawnego, który wymaga najpierw uformowania się autorytatywnej wspólnoty polis.

${ }^{9}$ W ważnej uwadze o Królu Learze Stanley Cavell zauważa, że Kordelia jest kozłem ofiarnym Leara, lecz Lear jest kozłem ofiarnym nas, widzów (CAVELL 2003, 75). Można to rozumieć tak, że dokonując swojego wyjścia $\mathrm{z}$ roli króla, przechodzi on na pozycję ofiary, w tym sensie, że wystawia się na nieograniczony żadna konwencją i władzą interpretujący wzrok widza, a co za tym idzie — jego osąd.

${ }^{10} \mathrm{~W}$ tym duchu interpretujemy uwagi Nussbaum o unikaniu (dobra resp. równoprawnych roszczeń) (NussBaum 1986, 46).
} 
funkcji, jakie pełnią w budowaniu pomyślności państwa. Wszystkie indywidualne dążenia, upodobania, zdolności powinny być, jego zdaniem, zorientowane na dobro państwa. Z kolei Antygona sprowadza wszystkie dobra do miłości rodzinnej (phylia) czy ogólniej — do więzi między ludźmi. Nussbaum rozumie wyrażenie „wszystkie dobra” dosłownie; zwraca uwagę, że nawet własne dobro Antygony nie liczy się w zestawieniu z relacjami, na których jej zależy. Antygona redukuje sama siebie w swoim uczuciu do brata ${ }^{11}$, nie uważa własnego życia ani pragnień za istotne, nie zwraca uwagi na innych ludzi. Liczą się tylko bliscy, którym jesteśmy winni lojalność (Nussbaum 1986, 64).

Jeśli spojrzeć na interpretację Nussbaum z punktu widzenia naszego założenia o warstwach tragedii, wina Agamemnona pojawi się jako związana $\mathrm{z}$ pierwszą z wyróżnionych przez nas warstw tragedii — jest działaniem wobec nieszczęścia, które w społecznym kontekście pojawia się zawsze w postaci sprzecznych roszczeń. Druga warstwa tragedii jest u Ajschylosa samym tylko uznaniem tego stanu i pójściem za najsilniejszym roszczeniem - pierwsza warstwa odwzorowuje się niejako w drugiej, następuje symboliczne powtórzenie. Natomiast u Sofoklesa sprzeczność roszczeń w warstwie podstawowej jest wzmocniona przez to, co zachodzi w warstwie drugiej, która wchodzi z pierwszą w interakcję. W drugiej warstwie pojawia się nowa siła, płynąca z samoodniesienia bohatera. Dlatego u Sofoklesa nie wystarczy już zwykłe pomijanie dóbr innych ludzi, jak u Ajschylosa. Trzeba te dobra aktywnie unieważnić ${ }^{12}$, sprawić, by straciły moc roszczenia. Moc roszczenia wyraża się w tym, że jesteśmy widziani przez innych, nasze czyny są odnotowane $\mathrm{w}$ zestawieniu $\mathrm{z}$ tym, co dla innych wartościowe czy słuszne a zatem ocenione. Dlatego tak ważną rolę $w$ tragediach odgrywa niewidzenie, utrata wzroku, okrutne oślepienie. Jak zobaczymy, Cavell pogłębia analizę tego wątku w swoim studium o Królu Learze (zob. CAvell 2003, 47; NusSBAum 1986, 78).

\footnotetext{
${ }^{11}$ Należałoby dodać: martwego brata, ponieważ nie wiemy nic o ich zażyłości za życia. Sofokles nie uważa tego za istotne.

${ }^{12}$ Redukcje, o których mowa, wyglądają wprawdzie jak decyzje aksjologiczne, jak ukształtowanie preferencji, w istocie jednak cały ten mechanizm jest napędzany pragnieniem, nie preferencją. Inaczej mówiąc, najpierw zachodzi konflikt pragnień, później dopiero konflikt przekonań, preferencji czy wartości. Oznacza to, że pragnienie działa zrazu na ślepo i dopiero stopniowo przybiera strukturę teleologiczną. Tak rozumiemy interesujące nawiązanie Nussbaum do Heraklita: konflikt jest konieczny, by widzieć dobra, stwierdza filozofka, a to dlatego, że tylko w świetle konfliktu uwidaczniają się roszczenia.
} 


\section{TRAGICZNA NEGACJA}

\section{JAKO RADYKALNY SCEPTYCYZM}

W Disowning Knowledge in Seven Plays of Shakespeare Stanley Cavell opisuje ducha sceptycyzmu, przenikającego całą nowożytność i oddziałującego na nas również dzisiaj. Nowożytność przesunęła problem niewiedzy na poziom bardziej podstawowy - niewiedza nie pochodzi z niepewności świata, jak twierdził sceptycyzm starożytny, lecz z negatywnego aktu podmiotu. Bohater tragiczny aktywnie odrzuca wiedzę jako podstawę życia, podważa wiarygodność nawet najdoskonalszego czy najbardziej oczywistego poznania. Tu właśnie ujawnia się głęboki związek sceptycyzmu i tragizmu.

Pierwszą odsłoną radykalnego sceptycyzmu jest u Szekspira gwałtowna, nieopanowana podejrzliwość i zazdrość. Leontes czy Otello, ogarnięci zazdrością, chcą wiedzieć na pewno, musza wiedzieć na pewno, że nie zostali zdradzeni. Nie widzą, że w ten sposób formułują standardy pewności, których osiągnąc się nie da. Najgłębszy poziom odżegnania się (disowning) od wiedzy widzi Cavell w Królu Learze. Ujawnia się w motywie oślepienia, interpretowanego przezeń jako odwrócenie niewidzenia: niebycie widzianym — usunięcie podmiotu ze świata. Gloucester zostaje oślepiony przez Corwalla, który nie tylko krzywdzi swojego wroga, lecz staje się dla niego, dla swej ofiary, niewidoczny ${ }^{13}$.

Sam Lear ucieka się do udawania i kłamstwa, które są również formą skrywania, czynienia niewidocznym. Strategią Leara jest nie wiedzieć — rozwinąć sztukę życia bez wiedzy. Lear uważa, że żyje w świecie Gorgiasza, w którym „kłamstwo jest lepszą dyspozycją do działania niż prawdomówność, a udawanie rozsądniejszą strategią niż szczerość" (CRITChley 2019, 21). Okrucieństwo, jakie Lear okazuje Kordelii, odrzucając jej miłość, jest, według Cavella, wyrazem tego fundamentalnego sceptycyzmu. Rozciąga się on na sferę więzi i komunikacji ${ }^{14}$. Lear przyjmuje $\mathrm{z}$ zadowoleniem retoryczne popisy pozostałych córek i odrzuca szczere zachowanie Kordelii, ponieważ uważa, że udawanie miłości jest lepsze. Racje Leara nie dadzą się jednak sprowadzić do pragmatycznego argumentu Gorgiasza. Nie chodzi

${ }^{13}$ Edyp w tragedii Sofoklesa pozbawia się wzroku po ujawnieniu prawdy, wyzbywając się fatalnej (bo autorytatywnej, trudnej do podważenia) zdolności do widzenia siebie, swoich czynów, a przez to czyniących go nieodwołalnie winnym.

${ }^{14}$ Między komunikacją i negacją roszczeń innych podmiotów zachodzi zależność podkreślona interesująco przez Jürgena Habermasa. Pisze on, że wprawdzie rozum komunikacyjny „,nie daje żadnej treściowej orientacji dla radzenia sobie z zadaniami praktycznymi”, lecz ,umożliwia orientowanie się na roszczenia ważnościowe” (HABERMAS 2005, 18). 
o lepsze radzenie sobie w świecie, lecz o uwolnienie się od ciężaru roszczenia. Nie wymusza też wewnętrznej odpowiedzi na to roszczenie, wymaga tylko odpowiedniego zachowania.

Problem w tym, że Lear naprawdę kocha Kordelię. Jak zauważa Cavell, udawanie miłości, kiedy się nie kocha, choć w oczywisty sposób nieszlachetne, jest często spotykane, natomiast udawanie miłości, kiedy sie kocha, jest czymś zupełnie innym - jest porażką wobec okrucieństwa świata, prewencyjnym odrzuceniem dobra $\mathrm{w}$ przekonaniu, że nie ma szans na jego realizację. W odrzuceniu Kordelii przez Leara tkwi przekonanie, że na najgłębszym dostępnym człowiekowi poziomie rzeczywistości miłość i jej brak są nieodróżnialne. Podobny stosunek ma Lear do wiedzy. Wiedza wydobywa na jaw dokonane już odrzucenie miłości, niosąc dodatkowe cierpienie, sama zaś nic nie wnosi. Dlatego Lear nie chce wiedzieć. W świecie pozoru i braku podstaw wybiera postawę adekwatną, czyli postawę niewiedzy.

Cavell sugeruje, że ten głęboki sceptycyzm, który tu próbujemy powiązać $\mathrm{z}$ doświadczeniem tragicznym, polega na rozczarowaniu. Zazwyczaj stan rozczarowania jest następczy — przychodzi po faktach, które rażąco przeczą naszym oczekiwaniom. Ale Szekspirowskie rozczarowanie jest inne - jest stanem pierwotnym: tragiczni bohaterowie Szekspira nie tyle doznają na koniec rozczarowania, co od niego zaczynają. Można nawet powiedzieć, że rozczarowanie tragiczne polega właśnie na niezdolności do rozczarowania w zwykłym sensie, kiedy to oczekiwania zderzają się boleśnie z realizacjami. Zwykłe rozczarowanie zakłada więzi i nadzieje oraz to, że wiedza jest sensowna, choć z jakichś powodów niemożliwa do zdobycia. Szekspirowski podmiot tragiczny nie podejmuje zmagań z niedoskonałością poznania, jego dramat rozgrywa się i kończy wcześniej. Jego nienawiść, chęć zemsty, jego rozczarowania mają charakter prewencyjny, żyje bowiem w wiecznym ,jeszcze nie" ${ }^{\prime 15}$.

W Szekspirowskim świecie relacja do innych ludzi nie opiera się na aprobowanych regułach, zobowiązaniach. Stosunkowo niewielką rolę odgrywa w nich empatia ${ }^{16}$. Głównym motorem działania jest tu pragnienie, a z punktu widzenia pragnienia - każdy inny podmiot, będący ośrodkiem własnych pragnień jest zagrożeniem. Jedyną bezpieczną relacją z innym człowiekiem

${ }^{15}$ Tak rozumiemy uwagę Cavella, że Hamlet ,,jeszcze się nie urodził” — jako syn, mężczyzna, książę. Paradoksalnie nie stał się jeszcze tym, kim był.

${ }^{16}$ Ogólne spostrzeżenia odnoszące się do Szekspira są prawie zawsze nietrafne: wystarczy przypomnieć sobie wielki monolog Shylocka z Kupca weneckiego, odwołujący się do empatii właśnie. Mówimy raczej o pewnym rzucającym się w oczy wątku. 
jest zawłaszczenie, sparaliżowanie jego woli, a tym samym zmniejszenie własnego ryzyka i związanego $\mathrm{z}$ nim lęku ${ }^{17}$. Czy będzie to obłędne dążenie do władzy Makbeta, czy patologiczna zazdrość Otella czy Leontesa, czy wreszcie pamiętliwość Prospera - wszędzie przejawia się ten sam wzorzec: posiadanie i władanie zastępują uczucia oparte na równoprawności.

[Jest to więź z samym sobą], której żadne roszczenie i żadne pragnienie nie mogą się przeciwstawić, czy nawet w ogóle się liczyć; tak jakby jego zazdrość skierowana była na czystą egzystencję innej osoby, na jej oddzielność od niego. (CAvell 2003, 9)

Bohater tragiczny nie może zaabsorbować innych egzystencji, posiąść całkowicie innego podmiotu. Dlatego przedmiot jego pragnienia wydaje mu się przez kogoś zabrany. $\mathrm{Z}$ tego powodu sceptycyzm Szekspirowski wyraża się nie $\mathrm{w}$ szyderstwie $\mathrm{z}$ naiwności czy melancholijnym zwątpieniu, lecz w zazdrości i żądzy zemsty.

Cavell podpowiada, że źródłem tragicznej negatywności jest uczucie pierwotnego wstydu, które źródłowo separuje każdego człowieka od innych ludzi. W diagnozie Cavella wstyd (implikowana przezeń separacja) jest właśnie przemieszczeniem podmiotu, które odpowiada za prewencyjne rozczarowanie i jego skutek: radykalny sceptycyzm. Jest $\mathrm{w}$ tym wiele racji. Istnieją wszak mity oparte na idei pierwotnego wstydu; również filozofowie, jak Scheler (2003) czy Sartre (2007, 333-339), potraktowali to uczucie z egzystencjalną powagą. Ale przy całej swej wadze jest to źródło przygodne $e^{18}$. Tymczasem raz ustanowiony radykalny sceptycyzm staje się konieczny, niemożliwy do obalenia, a przez to tragiczny. Wstyd przydarza się, trzeba sobie z nim radzić, lecz żeby uznać wstyd za przyczynę bezpodstawności wszelkiego działania, trzeba więcej: podmiot musi być zainteresowany utrzymaniem tej podstawy - głęboko z nią złączony. Ona nie może go tylko przygniatać nieszczęściem, bo byłaby wtedy niewiarygodna jako motywacja do działania.

Trzeba jednak powiedzieć, że z perspektywy Cavella nie da się w pełni pojąć wyobraźni tragicznej i siły jej oddziaływania, utrzymującej się przez tyle stuleci rozwoju gatunku tragedii w literaturze. Negatywność musi mieć

${ }^{17}$ Wyjątkiem są Szekspirowskie obrazy przyjaźni, zarówno w dramatach, jak w Sonetach, lecz nie możemy tu przedyskutować tego pasjonującego tematu.

${ }^{18}$ Trzeba odnotować, że Sartre prawdopodobnie nie zgodziłby się z tym twierdzeniem. Wstyd jest u niego kategorią analizy ontologicznej, w której pojawia się jako konieczny komponent relacji do innych. Rozważenie tej różnicy optyki wykroczyłoby jednak poza ramy tych rozważań. 
swoją pozytywność, grunt, na którym powstaje i utrzymuje się jako swoista egzystencjalna powinność. Wstyd wydaje się nam zbyt wątłym fundamentem tej konstrukcji. Pożądanego uzupełnienia dostarcza tu filozofia Lwa Szestowa, do której przejdziemy poniżej.

\section{TRAGICZNA NEGACJA JAKO NIEZAKORZENIENIE}

Trudno jednoznacznie określić, co w diagnozie Szestowa występuje jako chronologicznie pierwsze: sceptycyzm czy tragizm, łączą się one bowiem w specyficznym doświadczeniu nazwanym przez niego niezakorzenieniem. Odpowiedź na pytanie o pierwszeństwo rozwiązałaby wiele problemów interpretacyjnych związanych z filozofią Szestowa. Jeśli sceptycyzm rodzi sytuację tragiczną, to można powiedzieć, że u podłoża tragiczności Szestowowskiej tkwi akt negatywny, odmowny w stosunku do wiedzy i ludzkiego rozumu. Takie odczytanie ma podstawy. Szestow znany jest bowiem jako krytyk racjonalności. Z łatwością jednak można odwrócić ten porządek i powiedzieć, że tragizm u Szestowa wyłania się z pozytywnej rzeczywistości, mianowicie ze szczególnego doświadczenia. W tej interpretacji, człowiek zostaje uwikłany w tragiczność, nie zaś z góry o niej przesądza akt sceptycki wyłania się dopiero z pewnego przygodnego stanu rzeczy. Na poparcie tej wykładni można przytoczyć argument pozafilozoficzny. Zdaniem rosyjskiego myśliciela moment grzechu pierworodnego w symboliczny sposób zapoczątkowuje w człowieku pewne pęknięcie, które jest przyczyną jego tragicznej sytuacji w świecie - obarczony grzechem pierworodnym pozostaje niejako otwarty na sytuację tragiczną ${ }^{19}$.

Oba te kierunki interpretacji sytuacji tragicznej łączą się w Szestowowskim pojęciu niezakorzenienia. W polskich tłumaczeniach można się spotkać z takimi terminami, jak: niezakorzenienie, nieoczywistość, bezpodstawność czy doświadczenie tragedii. Termin rosyjski беспочвенность [bespochvennost'] odwołuje się do rosyjskiego porzekadła „потерял почву” [poteryal pochvu]. Najwłaściwiej byłoby go zatem porównać do polskiego zwrotu „utraty gruntu” czy określić mianem „bezgruncia”.

Zgodnie z Unamunowskim postulatem, by patrzeć na dzieła jako pisane przez „ludzi z krwi i kości” (UnAmuno 1984, 5), myśl Szestowa można potraktować jako studium przypadków tragicznych. Pisząc o Kierkegaardzie,

${ }^{19}$ Podnosi się czasem kwestię, czy myśl Szestowa należy do filozofii czy do teologii, lecz tu możemy ten problem tylko odnotować, nie dyskutując. 
Dostojewskim, Ibsenie czy Nietzschem, Szestow stara się wykazać, że poznanie rozumowe zawodzi w sytuacjach szczególnych. Interesują go autorzy, a nie bohaterowie dzieł, raczej Sofokles niż Król Edyp. Spowodowane jest to przeświadczeniem, że autorzy niejako ukrywają się za swoimi postaciami i próbują opisać coś, co trapi ich samych. W efekcie Szestowowski Szekspir zlewa się w jedność z Królem Learem, Dostojewski z Człowiekiem z podziemia, a Ibsen z Hjalmarem Ekdalem. W tym przypadku tragedia nie może być czystym wytworem wyobraźni pisarza, impulsem do jej powstania jest zazwyczaj konkretne wydarzenie ze świata rzeczywistego.

Zawarta w dziele Dostojewski i Nietzsche. Filozofia tragedii analiza życia i twórczości Dostojewskiego stała się modelem dla późniejszych Szestowowskich przykładów niezakorzenienia. Młody Dostojewski to człowiek pełen zapału, którego działaniom przyświecają wzniosłe idee: dobro, braterstwo i ogólnie pojęty humanizm. Na taki stan ducha wskazywać ma chociażby jego udział w organizacji Pietraszewców, grupy dyskusyjnej rozważającej między innymi dzieła Hegla czy Fouriera (WALICKI 2005, 237-238). W 1849 r. za udział w kole trafia do więzienia. Po przeciągającym się śledztwie uczestnicy grupy zostają skazani na śmierć. Szestow twierdzi, że ta wiadomość nie była jeszcze wystarczająca, aby wywołać u Dostojewskiego przełom - właściwe dla niezakorzenienia zwątpienie. Gdyby do egzekucji doszło, Dostojewski zapewne umarłby w chwalebnym poczuciu swego męczeństwa. Tymczasem młodzieńcom stojącym już przez plutonem egzekucyjnym złagodzono karę. Dostojewskiemu zamieniono ją na cztery lata katorgi.

Dostojewski wraca z niewoli odmieniony. Rozpoczyna się okres jego niezakorzenienia. Idee, które były tak istotne w życiu młodego pisarza, zdają się mu odpychające. Szestow stara się wykazać, że Dostojewski zaprzecza chociażby cenionemu wcześniej braterstwu, ponieważ z chwilą zwolnienia z katorgi przestaje myśleć o innych osadzonych. Wręcz instynktowne pragnienie powrotu do normalności i ucieczki od katorżniczych wspomnień jest silniejsze niż wartości przyjmowane przez Dostojewskiego w młodości. W zderzeniu z trudami życia wartości ulegają zniszczeniu, prowadzą do fundamentalnej odmiany człowieka.

Podobnie jak Cavell w stosunku do bohaterów Szekspira, Szestow mówi w odniesieniu do Dostojewskiego o rozczarowaniu. Podmiot zostaje wyrwany z poukładanego świata i przytrafia mu się coś, co jest nieoczekiwane i niezrozumiałe, poznaje granice rozumu i odtąd mu nie ufa. Radykalny akt odmowy dotyczy nie tylko rozumu, lecz także uczestnictwa w świecie. Podmiot nie jest w stanie podjąć pozytywnych działań, gdyż nie dostrzega ich sensu. 
W podanym schemacie możemy wyróżnić dwa procesy racjonalizacji: pierwotny i wtórny. (1) Pierwotny, związany z przyjęciem określonych idei, wyznacza ramy myślenia i działania. Nie przystają one do rzeczywistości, czego sprawdzianem są sytuacje tragiczne. (2) Racjonalizacja wtórna, zachodząca wtedy, gdy po dramatycznych doświadczeniach podmiot stara się powrócić do normalnego życia, wyznawanych wartości. Bywa, że podmiot potrafi wrócić do względnie spokojnego życia. Nigdy jednak nie wraca całkowicie do stanu sprzed niezakorzenienia. Trudne doświadczenie odciska na nim piętno. Nawet gdy ponownie zakorzenia się w ideach, nie jest już tym samym podmiotem, ponieważ przekształceniu ulega sam system wartości ${ }^{20}$.

Szestow postuluje utrzymanie stanu niezakorzenienia jako w pewnym sensie pożądanego. Wtórna racjonalizacja powinna zostać odżegnana na rzecz wytrwania w niezakorzenieniu. Praca Apoteoza niezakorzenienia. Próba myślenia dogmatycznego (SzESTOW 1983) ilustruje powinność wytrwałości w tym niełatwym, egzystencjalnym zawieszeniu. Podmiot nie ulega więc całkowitemu zniszczeniu czy degradacji, choć pozostaje mu w tej sytuacji niewiele, co u Szestowa przybiera hiperboliczną postać: „Nic, absolutnie nic nie powinno pozostać człowiekowi" (Szestow 1995, 243). Wydaje się, że niezakorzenienie odbiera człowiekowi racje do istnienia, także działania, a nawet myślenia. Żaden jednak $\mathrm{z}$ tych negatywnych stanów nie występuje w filozofii Szestowa. Wręcz przeciwnie, wskazuje on raczej na rozpościerające się tu możliwości: „Napotkacie tu rzeczywistość, nową niesamowitą, nieznaną, a raczej ukrywaną do tej pory i tych ludzi, którzy zmuszeni zostali nazywać ją swoją rzeczywistością, którym nie dane było powrócić do normalnego życia" (Szestow 1987, 109-110). Owe możliwości istnieją, choć nie są postrzegane przez podmiot niezakorzeniony jako pozytywne. Perspektywa taka jest widoczna $\mathrm{z}$ jedynie z pozycji interpretatora - filozofa tragedii.

Niezakorzenienie nie jest kuszącą perspektywą. Za cenę wyniszczenia, szaleństwa, utraty wszystkich racjonalnych „wygód” tego świata podmiot może uzyskać (w perspektywie doczesnej) jedynie satysfakcję z autentycznego bycia, obcowania z prawdziwym „żywym życiem” czy też mieć szansę na „twórczość z niczego". Dodatkowe możliwości otwierają się w perspektywie religijnej. Dla człowieka niezakorzenionego jedynym ratunkiem pozostaje sola fides - autentyczna, wolna od rozumu, niezakorzeniona wiara.

\footnotetext{
${ }^{20}$ Szestow pokazuje to na przykładzie Nietzschego, który ideę dobra zamienił na ideę nadczłowieka.
} 


\section{KONKLUZJA}

Broniliśmy tezy, że węzeł tragiczny powstaje nie tylko za sprawą konfliktu wartości, racji lub roszczeń, lecz także, a może przede wszystkim, za sprawą pewnego aktu odrzucenia lub redukcji wartości, sprawiającego, że bohater tragiczny od początku żyje w zawężonym polu aksjologicznym, niepozwalającym mu wybrać dobra i ocalić samego siebie. Odróżnienie pozytywnego i negatywnego aspektu sytuacji tragicznej nałożyliśmy na odróżnienie dwóch warstw tragedii: pierwsza obejmuje obiektywne nieszczęście i strategie oporu jego ofiary, druga dotyczy nowej interakcji między bohaterem i światem zmienionym przez jego działanie i intencje. Między tymi warstwami występuje wymiana, podobnie jak między negatywnym i pozytywnym aspektem tragedii. Opisanie tej wymiany — dynamiki sensu w obrębie ogólnego sensu tragiczności - tworzy hermeneutykę tragizmu, która nie zastępuje, lecz znacząco uzupełnia inne interpretacje tragedii. Filozoficzna analiza tragedii powinna zaczynać od aktu negatywnego, ponieważ pokazuje on zanurzenie tragedii w strukturze egzystencji. Obierając tę optykę, inspirowaliśmy się koncepcjami filozoficznymi, których bezpośrednim celem nie było wcale wyjaśnienie tragedii ${ }^{21}$, lecz mimo to rzucają światło na fenomen tragizmu. Możliwa jest jednak komplementarna wykładnia tragizmu, biorąca za punkt wyjścia pozytywny konflikt, zachodzący w doświadczeniu tragicznym, ulokowany w historii jednostki. Staraliśmy się pokazać tę wykładnię na przykładzie Szestowa, dla którego właściwsze jest raczej wytrwanie $\mathrm{w}$ stanie niezakorzenienia wywołanego doświadczeniem tragicznym aniżeli ryzykowne próby pozbycia się tego doświadczenia za pomocą samointerpretacji, doznania katarktycznego czy pewnej polityki pragnienia. Pozostaje pytanie, czy podobna do Szestowowskiej strategia wytrwania nie powinna działać również $\mathrm{w}$ domenie radykalnego sceptycyzmu (prewencyjnego rozczarowania). Radykalna negatywność nie zniknie bowiem, raz ustanowiona, ani z horyzontu kultury, ani jako możliwość egzystencji. Może jednak przyjąć nowe formy, które dziś jeszcze nie jawią się jasno, i nowe strategie podmiotu, które trudno przewidzieć. $\mathrm{Na}$ to pytanie nie mamy odpowiedzi, choć sądzimy, że w każdej z omówionych tu interpretacji tragizmu tkwią jakieś jej fragmenty.

${ }^{21}$ Nussbaum interesuje pytanie etyczne — o możliwość czynienia dobra w przygodnym świecie, a Cavella interesuje sceptycyzm jako inherentna własność nowożytnej kultury. 


\section{BIBLIOGRAFIA}

AdAmCZewski, Zygmunt. 1969. Tragiczny protest. Warszawa: PIW.

BILLINGS, Joshua Henry. 2011. The theory of tragedy in Germany around 1800: a genealogy of the tragic. $\mathrm{PhD}$ dissertation, Merton College.

Cavell, Stanley. 2003. Disowning Knowledge in Seven Plays of Shakespeare. Cambridge: Cambridge University Press.

Critchley, Simon. 2019. Tragedy, the Greeks and Us. New York: Pantheon Books.

Habermas, Jürgen. 2005. Faktyczność i zobowiąanie. Teoria dyskursu wobec zagadnień prawa i demokratycznego państwa prawnego. Przełożyli Adam Romaniuk i Robert Marszałek. Warszawa: Scholar.

HüHn, Lore, i Philipp Schwab. 2011. Die Philosophie des Tragischen: Schopenhauer - Schelling - Nietzsche. Berlin: De Gruyter.

Menke, Christopher. 2005. Die Gegenwart der Tragödie. Versuch über Urteil und Spiel. Frankfurt am Main: Suhrkamp.

Nietzsche, Fryderyk. 1907. O pochodzeniu tragedii z ducha muzyki. Tłum. Leopold Staff. Warszawa: Nakładem Mortkowicza. Również jako NieTzsCHE, Fryderyk. 2011. Narodziny tragedii albo Grecy i pesymizm. Tłum. Bogdan Baran. Warszawa: Aletheia.

Nussbaum, Martha. 1986. The Fragility of Goodness. Luck and Ethics in Greek Tragedy and Philosophy, Cambridge: Cambridge University Press.

SARTre, Jean-Paul. 1998. Egzystencjalizm jest humanizmem. Przełożyli Krystyna Szeżyńska-Maćkowiak i Janusz Krajewski. Warszawa: Muza.

SARtre, Jean-Paul. 2007. Byt i nicość. Przełożyli Jan Kiełbasa, Piotr Mróz, Rafał Abramciów, Remigiusz Ryziński i Paulina Małochleb. Kraków: Zielona Sowa.

SCHElER, Max. 1976. „O zjawisku tragiczności”. Tłum. Roman Ingarden. W: Arystoteles, David Hume, Max Scheler. O tragedii i tragiczności. Opracował Władysław Tatarkiewicz. Kraków: Wydawnictwo Literackie.

SCHELER, Max. 2003. „O wstydzie i poczuciu wstydu”. Tłum.a Marzena Świtalska. W: Wstyd i nagość, red. Marian Grabowski, Toruń: Wydawnictwo UMK.

Szestow, Lew. 1983. Apoteoza niezakorzenienia. Próba myślenia dogmatycznego. Przełożyli Nina Karsov i Szymon Szechter. Warszawa: Kontra.

Szestow, Lew. 1987. Filozofia tragedii. Dostojewski i Nietzsche. Tłum. Cezary Wodziński. Warszawa: Czytelnik.

Szestow, Lew. 1995. Sola fide. Tylko przez wiare. Tłum. Cezary Wodziński. Warszawa: Wydawnictwo Naukowe PWN.

Szond, Péter. 2020. Esej o tragiczności. Tłum. Tadeusz Zatorski. Warszawa: Fundacja Augusta Hrabiego Cieszkowskiego.

Unamuno, Miguel. 1984. O poczuciu tragiczności życia wśród ludzi i wśród narodów. Tłum. Henryk Woźniakowski. Kraków/Wrocław: Wydawnictwo Literackie.

WALICKI, Andrzej. 2005. Zarys myśli rosyjskiej. Od oświecenia do renesansu religijno-filozoficznego. Kraków: Wydawnictwo Uniwersytetu Jagiellońskiego.

WeIL, Simon. 1961. „Zakorzenienie”. W: Zakorzenienie i inne fragmenty. Wybór pism. Thum. Andrzej Wielowieyski. Kraków: Znak. 


\section{TRAGEDIA I SCEPTYCYZM}

\section{Streszczenie}

Najbardziej rozpowszechniona interpretacja sytuacji tragicznej odwołuje się do pozytywnego konfliktu sił lub wartości. W artykule badamy inną możliwość: skupienie się na uwikłanym w tragedię akcie negatywnym, czyli odżegnaniu się bohatera tragicznego od istotnych dóbr i więzi, sprawiającym, że od początku żyje on w zawężonym świecie, w którym nie da się ani wybrać dobra, ani ocalić samego siebie. Odróżnienie pozytywnego i negatywnego aspektu sytuacji tragicznej zestawiamy $\mathrm{z}$ odróżnieniem dwóch warstw tragedii. Pierwsza obejmuje obiektywne nieszczęście i strategie oporu ofiary, druga obejmuje nową interakcję między podmiotem i rzeczywistością zmienioną przez jego opór. Ta nowa interakcja powiększa nieszczęście i jest źródłem tragicznej winy. Pomiędzy obiema warstwami występuje dynamiczna wymiana treści, podobnie jak między negatywnym i pozytywnym aspektem tragedii. Akt negatywny (odrzucenie wartości i więzi) oraz pozytywny (konflikt wartości, racji, roszczeń) są wzajemnie uwikłane. Interpretacja tragedii wymaga śledzenia obu kierunków ich interakcji. Właściwe jest, by hermeneutyka filozoficzna zaczynała od aktu negatywnego, ponieważ pokazuje on zanurzenie tragedii w strukturze egzystencji. Nie usuwa to jednak potrzeby innej hermeneutyki, rozpoczynającej od doświadczenia tragicznego. Staraliśmy się pokazać tę możliwość, odwołując się do fillozofii Lwa Szestowa.

Słowa kluczowe: tragedia; sceptycyzm; hermeneutyka; niezakorzenienie.

\section{THE TRAGEDY AND THE SKEPTICISM}

\section{Su m mary}

The well-trotted path of interpretation of tragedy refers to a positive conflict of forces or values. In this article, we examine another possibility: to focus on a negative act involved in the tragedy, i.e., avoidance of essential goods and attachments. The avoidance makes the tragic hero live in a contracted world in which he cannot choose a good or save himself. The distinction between the positive and negative aspects of a tragic situation intersects with the distinction between the two layers of tragedy. The first layer involves unfortunate events and the subject's strategies of resistance and self-preservation. The second layer involves new interactions between the subject, and the new reality changed by the effort of resistance. The new interaction leads to tragic guilt and turns the subject into a tragic hero. Between these layers, there is a dynamic exchange of content as it is between the negative and positive aspects of the tragedy. The negative act (rejection of values and attachments) and the affirmative act (the stand taken in an actual conflict of values, rations, claims) are mutually entangled. Any viable interpretation of tragedy should be able to follow both directions of their interaction. It is natural for philosophical hermeneutic to start with the negative act because it shows the immersion of tragedy in the structure of existence. This approach does not, however, remove the need for another hermeneutics, starting with the tragic experience. We tried to show this possibility by referring to the philosophy of Lev Shestov.

Keywords: tragedy; skepticism; hermeneutics; groundlessness. 


\section{Information about the Authors:}

Prof. Dr. habil. Robert PIŁAT - The Cardinal Stefan Wyszyński University, Faculty of Christian Philosophy, Institute of Philosophy, Chair of Theory of Knowledge; correspondence address: ul. Wóycickiego 1/3, bud. 23, 01-938 Warszawa; e-mail: r.pilat@uksw.edu.pl; ORCID: 00000001-7712-7032.

Martyna FilceK, MA - The Cardinal Stefan Wyszyński University, Faculty of Christian Philosophy, Institute of Philosophy, PhD student; correspondence address: ul. Wóycickiego 1/3, bud. 23, 01-938 Warszawa; e-mail: filcekmartyna@gmail.com; ORCID: 0000-0002-3689-3483. 